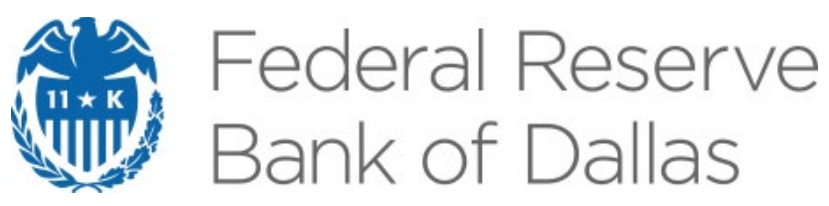

\title{
Container Trade and the U.S. Recovery
}

Lutz Kilian, Nikos Nomikos and Xiaoqing Zhou

Working Paper 2108

June 2021

Research Department

https://doi.org/10.24149/wp2108

Working papers from the Federal Reserve Bank of Dallas are preliminary drafts circulated for professional comment. The views in this paper are those of the authors and do not necessarily reflect the views of the Federal Reserve Bank of Dallas or the Federal Reserve System. Any errors or omissions are the responsibility of the authors. 


\title{
Container Trade and the U.S. Recovery ${ }^{*}$
}

\author{
Lutz Kilian ${ }^{\dagger}$ Nikos Nomikos ${ }^{\ddagger}$ and Xiaoqing Zhou ${ }^{\S}$
}

June 17, 2021

\begin{abstract}
Since the 1970s, exports and imports of manufactured goods have been the engine of international trade and much of that trade relies on container shipping. This paper introduces a new monthly index of the volume of container trade to and from North America. Incorporating this index into a structural macroeconomic VAR model facilitates the identification of shocks to domestic U.S. demand as well as foreign demand for U.S. manufactured goods. We show that, unlike in the Great Recession, the primary determinant of the U.S. economic contraction in early 2020 was a sharp drop in domestic demand. Although detrended data for personal consumption expenditures and manufacturing output suggest that the U.S. economy has recovered to near $90 \%$ of prepandemic levels as of March 2021, our structural VAR model shows that the component of manufacturing output driven by domestic demand had only recovered to $57 \%$ of prepandemic levels and that of real personal consumption only to $78 \%$. The difference is mainly accounted for by unexpected reductions in frictions in the container shipping market.
\end{abstract}

JEL Codes: E32, E37, F47, F62.

Keywords: Merchandise trade, container, shipping, manufacturing, consumption, COVID-19, supply chain, recession, recovery, globalization.

\footnotetext{
* The views in this paper are solely the responsibility of the authors and should not be interpreted as reflecting the views of Federal Reserve Bank of Dallas or the Federal Reserve System. We thank Marc Giannoni, Ana María Herrera and Antonella Teodoro for helpful discussions. The authors have no conflict of interest to disclose.

${ }^{\dagger}$ Lutz Kilian, Federal Reserve Bank of Dallas, Research Department, 2200 N. Pearl St., Dallas, TX 75201, USA. E-mail: Ikilian2019@gmail.com.

${ }^{\ddagger}$ Nikos Nomikos, Bayes Business School (formerly Cass Business School), 106 Bunhill Row, London EC1Y 8TZ, UK. Email: N.Nomikos@city.ac.uk.

§Xiaoqing Zhou, Federal Reserve Bank of Dallas, Research Department, 2200 N. Pearl St., Dallas, TX 75201, USA. Email: xqzhou3@gmail.com.
} 


\section{Introduction}

An essential feature of the globalization of the economy since the 1990s has been the growing importance of sea-borne container trade. With $90 \%$ of non-bulk dry cargo globally being shipped by container, there is a close relationship between the volume of container trade and domestic economic activity. For example, domestic manufacturing firms rely on imports of containerized raw materials and intermediate goods, while consumers routinely purchase finished goods arriving in the United States by container. Ours is the first study to use fluctuations in the volume of container trade to help understand the business cycle in the United States and the state of the economic recovery from the COVID-19 Recession.

We introduce a new monthly index of the volume of container trade to and from North America that is available since January 1995. The advantage of our index is that it is available for a longer time span than alternative indices, which facilitates its use for business cycle analysis. Incorporating this container trade index into a structural macroeconomic vector autoregressive (VAR) model facilitates the identification of shocks to domestic U.S. demand as well as foreign demand for U.S. manufactured goods. Unlike conventional empirical models of the macroeconomy, our model accounts for the fact that global supply chains leave manufacturers vulnerable to disruptions if a necessary part does not reach an assembly plant in time. The lack of key parts may reduce output, employment, and income for individual companies by amounts larger than the value of the delayed part and in areas and businesses far removed from the port where a disruption occurred. Our model also allows for unexpected frictions in container shipping markets such as labor strife, port congestion, shipping delays or shortages along the supply chain to affect domestic economic activity.

We use this model to compare the determinants of U.S. manufacturing output and real personal consumption during the COVID-19 Recession of 2020-21 and the Great Recession of 2007-09. We show that, unlike during the Great Recession, when a gradual decline in 
manufacturing output driven by lower domestic demand was reinforced by a persistent decline in foreign demand, the primary determinant of the U.S. economic contraction in early 2020 was a sharp drop in domestic demand. Moreover, whereas lower domestic demand caused only a modest decline in real personal consumption during the Great Recession, it created a sharp drop in real personal consumption in 2020.

Although detrended data for personal consumption expenditures and manufacturing output suggest that the U.S. economy as of March 2021 has recovered to near $90 \%$ of prepandemic levels, our structural VAR model shows that the recovery of U.S. domestic demand remains slow. For example, the component of manufacturing output driven by domestic demand has only recovered to $57 \%$ of pre-pandemic levels. The difference is explained by the effects of other shocks including, most importantly, reduced frictions in the container shipping market. Similarly, the component of real personal consumption driven by domestic demand has only recovered to $78 \%$ of pre-pandemic levels, compared with the $94 \%$ recovery observed in the raw data. Again, the difference is mostly accounted for by reduced frictions in the container shipping market.

We also draw attention to the differential effect of domestic demand shocks on U.S. real personal consumption of services and of goods. The component of goods consumption driven by domestic demand shocks did not decline nearly as much in early 2020 as the corresponding component of overall consumption, and since April 2020 has recovered to $150 \%$ of pre-pandemic levels, compared with only $78 \%$ for overall consumption. When further disaggregating goods consumption, we find that the recovery of durables consumption to $190 \%$ of its pre-pandemic level in early 2021 has been mainly driven by domestic demand, reinforced not only by reduced frictions in container shipping markets, but also by higher foreign demand for durables produced in the United States. The recovery of nondurables consumption to $184 \%$ of its pre-pandemic level, in contrast, has been driven almost entirely 
by domestic demand.

Finally, we show that estimates of the cumulative contribution of each shock line up well with extraneous anecdotal evidence about structural changes in the container shipping market during the Great Recession and the COVID-19 Recession (see Notteboom, Pallis and Rodrigue 2021). We also examine the feedback from domestic demand shocks and shocks to the foreign demand for U.S. manufactured goods to the volume of North American container shipping. We document that these shocks jointly explain about one third of the variation in the volume index with the remainder reflecting shocks specific to the container shipping market as well as unexpected shifts in the foreign supply of consumer and intermediate goods. Conversely, our model shows that, on average, shocks related to frictions in the container shipping market have a nontrivial effect on the U.S. economy. They account for $29 \%$ of the variation in U.S. manufacturing relative to trend and $38 \%$ of the variation in detrended real personal consumption.

Our work complements a growing literature on container shipping markets. It is widely recognized that the widespread adoption of containerized shipping since the 1990s constitutes one of the most important changes in the transportation sector in the twentieth century (see Hummels 2007). Many earlier studies of the container shipping market focused on the issue of route optimization and fleet development (e.g., Lee and Song 2017, Jeon 2020), on the impact of transportation costs on the location of economic activity and trade patterns (e.g., Behrens and Picard 2011; Ishikawa and Tarui 2018; Wong 2020), and on how the reduction in trade costs caused by the containerization of cargo has stimulated global trade (e.g., Bernhofen, El-Sahli and Kneller 2016; Cosar and Demir 2018). Our focus on the interaction between container trade, global supply chains, and U.S. economic activity, in contrast, is new to the literature. Our analysis also complements existing work on the relationship between input and output inventories and the business cycle such as Humphreys, 
Maccini and Schuh (2001) and Wen (2011).

The remainder of the paper is organized as follows. In Section 2, we motivate our interest in container transport and derive our index of the volume of North American container trade (NACTI). We then contrast this index to alternative container trade indices and link fluctuations in the volume of container trade to the global business cycle and the U.S. business cycle. In Section 3, we introduce a structural vector autoregressive (VAR) model of the interaction between the NACTI and the U.S. economy. The empirical results are discussed in Section 4. The concluding remarks are in Section 5.

\section{Measuring the Volume of Container Trade}

Since the 1970s, exports and imports of manufactured goods have been the engine of international trade and much of that trade relies on container shipping. This paper introduces a new monthly index of the volume of container trade to and from North America that is available since January $1995 .^{1}$

\subsection{Institutional background}

Intermodal transport of freight in reusable containers of standardized dimensions has revolutionized the global transportation of goods since the 1960s and has played a central role in the globalization of the economy since the 1990s. Containerized cargo is carried by specialized ocean-going vessels and transferred to rail cars or trucks at the seaport. Containers come in several different sizes with 20 -foot and 40 -foot containers being most commonly used. Most cargo containers in the world are general purpose containers that are used for cartons, boxes, cases, pallets, drums, and other standard goods. There are also refrigerated containers for perishable goods, tank containers for liquid goods, open-top

\footnotetext{
${ }^{1}$ Our index differs from earlier efforts to proxy the evolution of the global volume of bulk dry cargo in that it focuses on trade in manufactured goods rather than in raw materials. It also differs from indices proxying for global or regional industrial production in that it is designed to measure container trade rather than real economic activity. Further discussion of related indices can be found in Kilian and Zhou (2018).
} 
containers for bulk cargoes and agricultural commodities, and flat-rack containers for heavy machinery. The largest container vessels carry up to 24,000 TEU (twenty-foot equivalent unit) containers. The containerization of sea transport has greatly reduced the time and expense it takes to trade goods (see Hummels 2007). This reduction in trade costs in turn has been a key driver of global trade in recent decades (see Bernhofen, El-Sahli and Kneller 2016; Cosar and Demir 2018). Today, $60 \%$ of the value of seaborne trade and nearly $90 \%$ of non-bulk dry cargo is transported as containerized cargo, including most trade in manufactured goods.

\subsection{The NACTI index}

The analysis in this paper is based on a new index of the volume of container trade to and from North America. We focus on the container throughput, a standard measure of container handling, defined as the sum of all TEUs processed at a port in a given month, whether empty or loaded. ${ }^{2}$ Container throughput includes containers imported to or exported from a port as well as containers stored for transshipment. ${ }^{3}$ The definition of container throughput therefore is very similar to that of other measures of international trade. One advantage of container trade is that TEU data for most major U.S. and Canadian seaports are available with a delay of only one month. This makes these data more relevant for business cycle analysis than the annual container trade data provided by the United Nations Conference on Trade and Development (UNCTAD). Moreover, data revisions tend to be minor compared to other trade data, which makes it easier to evaluate the index in real time.

For the purpose of constructing an index of the volume of North American container

\footnotetext{
${ }^{2}$ The inclusion of shipments of empty containers in the index is justified by the fact that containers are valuable assets in their own right and their timely positioning is important for the smooth functioning of global supply chains. Often, in periods of strong demand, container companies prefer to ship containers back to their ports of origin empty in order to fill them up as soon as possible.

${ }^{3}$ There are few containers landing in the United States that are subsequently shipped to other countries, so transshipments are quantitatively unimportant for North American container trade.
} 
trade, we selected all ports that processed more than 1.5 million TEUs in 2018 , as shown in Table 1. These ports, which are located along the Pacific Coast, the Atlantic Coast and the Gulf Coast, account for $89 \%$ of the total volume of container traffic to and from the United States and for $76 \%$ of container traffic to and from Canada. Figure 1 shows the raw TEU data that were manually compiled from U.S. and Canadian port statistics. We construct the overall index for the United States by cumulating the growth rate of TEUs for all ports combined, for which TEU volume growth rates can be computed. This is equivalent to imputing the missing monthly observations based on the rate of TEU growth for the seaports that report data and then expressing the resulting index on a log scale. Figure 2 shows that virtually identical results are obtained whether including Canadian ports in the index or not. Given the close relationship between the U.S. and Canadian economies, including the exchange of intermediate products along the value chain, we focus on the combined index in the remainder of the paper. ${ }^{4}$ Figure 3 shows this index after removing the inherent seasonality with the MATLAB X-13 toolbox for seasonal filtering. We refer to this index as the North American Container Trade Index (NACTI). Figure 3 illustrates that the volume of North American container trade has more than tripled since 1995.

\subsection{Other container trade indices}

Our NACTI index is not the first monthly index of container trade volumes to be developed, but is the longest such index we are aware of. Perhaps best known is the global monthly container trade index that has been published by the Institute of Shipping Economics and Logistics (ISL) in Bremen, Germany, and the Leibniz-Institut für Wirtschaftsforschung (RWI) in Essen, Germany, since 2012. The RWI/ISL index is constructed along similar lines

\footnotetext{
${ }^{4}$ A similar argument could be made for Mexico, which is part of the same NAFTA/USMCA agreement. We did not include data for Mexico, given that monthly data for the container throughput of Mexican ports is not easily available.
} 
as the NACTI. ${ }^{5}$ Currently, the RWI/ISL database consists of 91 international ports covering more than $60 \%$ of world container shipping, including ports in Asia, the Americas, Europe, Oceania and Africa. The same source also provides regional disaggregates including data for Canada and the United States. In fact, the North American ports included in the RWI/ISL index match those used in constructing the NACTI. Unlike the NACTI, however, the global RWI/ISL container trade index is only available starting in January 2007.

Döhrn and Maatsch (2012) and Döhrn (2019) show that the RWI/ISL index is highly correlated with measures of global trade, as reported by the IMF, and may be used as an early indicator of changes in global trade (see, e.g., OECD 2020, p. 4). Of equal interest is the statistical relationship between this index and the OECD's index of industrial production in the OECD and in six emerging economies. ${ }^{6}$ Table 2 shows that the index is highly procyclical when log-linearly detrending the data with a contemporaneous correlation with global industrial production of $88 \%$. Likewise the cross-autocorrelation of world industrial production with near leads and lags of the RWI/ISL index remains high. Table 3 shows a much smaller positive contemporaneous correlation among the growth rates with some evidence that global container trade volumes lead growth in world industrial production by two months.

While suggestive, this evidence does not speak directly to the relationship between container trade volumes and specific economies such as the U.S. economy. One reason is that regional container trade indices may evolve quite differently from the global index, as we demonstrate next. For expository purposes we focus on the NACTI as well as the "North range" subindex reported by RWI/ISL based on data from the ports of Le Havre, Zeebrugge, Antwerp, Rotterdam, Bremen/Bremerhaven, and Hamburg. The North range index covers the

\footnotetext{
${ }^{5}$ The data and further documentation are available at: https://www.isl.org/en/containerindex.

${ }^{6}$ The original index was discontinued by the OECD. We rely on an updated version of this index made available at https://econweb.ucsd.edu/ jhamilto/software.htm.
} 
bulk of sea-borne container trade in central Europe. Figure 4 shows this index along with the NACTI and the global RWI/ISL index. All three indices have been log-linearly detrended for expository purposes.

Figure 4 illustrates that there are substantial regional differences in the evolution of container trade indices that are obscured by the global index. Not only is the NACTI generally less smooth than the other indices, but, more importantly, its level and rate of change may also differ markedly. This means that a global index is less suitable for understanding the interaction of the U.S. economy with the container shipping market than the NACTI developed in this paper. For example, the NACTI declined in early 2008 well before the global index and the North range index did. Moreover, the NACTI was systematically below the global index in 2011-14 and systematically above the global index in 2015-2018. ${ }^{7}$ Finally, whereas the global index remained stable in early 2021 and the North range index drops, consistent with tightening virus protocols in Europe, the NACTI dramatically improved. An important question addressed in the remainder of the paper is whether this surge in 2021 reflected a recovery of U.S. demand or foreign demand for U.S. manufactured goods, which would signal a strong U.S. recovery, or whether it is an artifact of other shocks in the global container shipping market.

\subsection{The NACTI and the U.S. business cycle}

A deeper understanding of the relationship between the NACTI and the U.S. economy may be obtained by not focusing on its relationship with overall U.S. real economic activity, but on the relationship with two monthly macroeconomic aggregates that a priori are likely to be closely tied to container trade. One series is U.S. industrial production of manufactured

\footnotetext{
${ }^{7}$ A striking feature of the NACTI not shared by other indices is the sharp drop in early 2015 , followed by a strong reversal. These spikes reflect a protracted labor dispute that lasted from late 2014 to February 2015 and affected nearly 30 ports on the West Coast, causing protracted disruptions in container shipping, followed by frantic efforts to make up for lost time, once the dispute was resolved.
} 
goods. Not only are such goods typically exported by container, but the supply chain of U.S. manufacturers heavily relies on imports of containerized cargo. The other series is U.S. real personal consumption of goods. ${ }^{8}$ Given that most U.S. consumer goods in recent years have been either imported by container or produced from intermediate products that arrive in the United States by container, there is a close connection between the availability of consumer goods and container trade.

Table 4 confirms that, after linear detrending, the NACTI is highly procyclical with both of these variables, especially with real personal goods consumption. The contemporaneous correlation is $67 \%$ for manufactured output and $73 \%$ for goods consumption, which clearly exceeds the $60 \%$ correlation with the overall index of U.S. industrial production. Likewise, the cross-autocorrelations with the NACTI are consistently high even at leads and lags of two months. Table 5 shows much smaller and in some cases barely positive correlations in growth rates, suggesting a much weaker statistical relationship, arguably because of the more erratic evolution of the NACTI compared with these U.S. macroeconomic aggregates.

This reduced-form evidence is suggestive, but leaves unanswered the question of what exactly the relationship is between these variables. We provide a tentative answer to this question in the next section which introduces a structural VAR model designed to quantify the feedback from shocks to the demand for consumer goods and for manufacturing goods produced in the United States. Our baseline model utilizes the full length of available data for the NACTI since January 1995, which is essential for disentangling the cumulative effects of alternative shocks during the Great Recession and the COVID-19 Recession, given the need to discard transient observations. The choice of the variables is deliberate to help us identify the interaction between the container shipping market and the U.S. economy. In the baseline

\footnotetext{
${ }^{8}$ Both series were downloaded from FRED.
} 
model, we work with a broad measure of real personal consumption. ${ }^{9}$ Alternative models based on disaggregate consumption data for goods, durables and nondurables are examined in Section 5 .

\section{A Structural Interpretation of the Interaction of the U.S. Economy and North}

\section{American Container Trade}

Let $y_{t}=\left(u s r p c_{t}, \text { usipm }_{t}, N A C T I_{t}\right)^{\prime}$ be generated by a covariance stationary structural VAR(12) process of the form $B_{0} y_{t}=B_{1} y_{t-1}+\ldots .+B_{12} y_{t-12}+w_{t}$, , where $u s r p c_{t}$ denotes loglinearly detrended U.S. real personal consumption, usipm $_{t}$ denotes log-linearly detrended U.S. industrial production of manufactured goods, and $N A C T I_{t}$ denotes the linearly detrended index of North American container trade (see Figure 5). ${ }^{10}$ The stochastic error $w_{t}$ is mutually uncorrelated white noise and the deterministic terms have been suppressed for expository purposes. All data are monthly. The estimation period is January 1995 to March 2021. We follow Kilian and Lütkepohl (2017) in setting a conservative lag order of 12, which avoids the pitfalls of data-based lag order selection.

The reduced-form errors may be written as $u_{t}=B_{0}^{-1} w_{t}$, where $B_{0}^{-1}$ denotes the structural impact multiplier matrix, $u_{t}=y_{t}-A_{1} y_{t-1}-\ldots-A_{12} y_{t-12}$, and $A_{l}=B_{0}^{-1} B_{l}, l=1, \ldots, 12$. The $\{i j\}$ th element of $B_{0}^{-1}$, denoted $b_{i j}^{0}$, represents the impact response of variable $i$ to structural shock $j$, where $i \in\{1, \ldots, 3\}$ and $j \in\{1, \ldots, 3\}$. Given the reduced-form estimates, knowledge of $B_{0}^{-1}$ suffices to recover estimates of the structural impulse responses, variance decompositions and historical decompositions from the reduced-form estimates, as discussed

\footnotetext{
${ }^{9}$ Although services are not tradable, the case can be made that service providers purchase goods that are imported in containers, motivating the use of a broader measure of real personal consumption as the baseline. ${ }^{10}$ Detrending these data facilitates the construction of historical decompositions and variance decompositions. The impulse response estimates are robust to estimating the same model in levels.
} 
in Kilian and Lütkepohl (2017).

\subsection{Identifying assumptions}

A positive domestic demand shock in the United States is expected to raise all three model variables on impact. The model allows the response of these variables to be freely estimated. A positive impact effect of higher domestic demand on the NACTI in particular makes sense because it normally takes only between two and three weeks for containerized cargo from many ports in Europe to arrive on the East Coast of the United States, making it important to allow for instantaneous feedback to container trade. Likewise, it makes sense to allow for an instantaneous production response from U.S. manufacturers with inventories of raw materials and intermediate products, even granting that there are manufacturers that may require a lead time of more than one month before being able to raise production. This is largely an empirical question. If such constraints are important in the data, the estimated positive impact response will be small.

In contrast, a positive shock to the foreign demand for manufactured goods produced in the United States is expected to raise U.S, industrial output for manufactured goods as well as the NACTI on impact, while raising real personal consumption only with a delay. The positive impact response in the NACTI in this case reflects imports of containerized intermediate products as well as exports of manufactured goods.

Finally, a positive shock to frictions in the container shipping market affects U.S. aggregates only with a delay, given the existence of inventories which act as a buffer against disruptions of container trade. Such shocks may arise from unexpected changes in port processing times due to congestion or labor strife (as exemplified by the 2014/15 West Coast labor dispute, which caused major swings in the index). They may also reflect fluctuations in the availability of shipping containers and in the availability of container vessels for specific routes. Another example of such shocks are weather-related early and late arrivals of 
container ships or other disruptions of shipping such as the grounding, in March 2021, of the 20,000 TEU "Ever Given" in the Suez Canal which lasted for six days and disrupted the trade between Asia, Middle East and Europe. Delays in container shipping are nontrivial. For example, as of March 2021, only about $40 \%$ of container ships arrived on time, down from more than $70 \%$ two years ago.

Most importantly, this shock captures shifts in the supply of container cargo produced abroad that affect the availability of consumer goods and manufactured goods in the United States. Any disruption in the supply chain elsewhere in the world is likely to cause delays in container shipments, which may cause large and widespread disruptions in industrial production in the United States. A shortage of semi-conductors in China, for example, may

slow the production of automobiles in the United States, while also restricting the availability of consumer electronics for purchase in the United States. Likewise, changes in trade policy may cause disruptions to the supply chain, as exemplified by some of the policy shifts under the Trump administration (see Flaaen and Pierce 2019).

The macroeconomic importance of unexpected disruptions of global supply chains is well recognized among policymakers. For example, in a 2006 report, the Congressional Budget Office noted that "[c]ontainerized imports include both finished goods and intermediate inputs, some of which are critical to maintaining U.S. manufacturers' ... supply chains. Such supply chains ... leave manufacturers vulnerable to disruption if a necessary part does not reach an assembly plant in time. The lack of key parts could reduce output, employment, and income for individual companies by amounts larger than the value of the delayed part—and in areas and businesses far removed from the port where a disruption occurred" (p. 1).

\subsection{Estimation and inference}

This simple, yet economically intuitive model not only allows us to assess the dependence of 
the NACTI on shocks to domestic demand in the United States and foreign demand for U.S. manufactured products, but also helps quantify the extent to which U.S. real personal consumption and U.S. manufacturing output have responded to these shocks during 2020/21 compared with the Great Recession of 2007-09. The model may be represented succinctly as:

$$
\left(\begin{array}{c}
u_{t}^{U . S . R P C} \\
u_{t}^{U . S . I P M} \\
u_{t}^{\text {NACTI }}
\end{array}\right)=\left[\begin{array}{ccc}
b_{11}^{0} & 0 & 0 \\
b_{21}^{0} & b_{22}^{0} & 0 \\
b_{31}^{0} & b_{12}^{0} & b_{13}^{0}
\end{array}\right]\left(\begin{array}{c}
w_{t}^{\text {domestic demand }} \\
w_{t}^{\text {foreign demand }} \\
w_{t}^{\text {container market friction }}
\end{array}\right) .
$$

The identifying restrictions render $B_{0}^{-1}$ recursive, allowing us to recover this matrix as the lower triangular Cholesky decomposition of the reduced-form error covariance matrix $\Sigma$ with the diagonal elements normalized to be positive. The model is estimated by Bayesian methods using a diffuse Gaussian-inverse Wishart reduced-form prior, as described in the appendix (see Karlsson 2013). Having simulated the posterior distribution of the structural impulse responses based on 2,000 posterior draws, we evaluate the joint impulse response distribution under additively separable; absolute loss, as discussed in Inoue and Kilian (2021).

\section{Empirical Results for Baseline Model}

\subsection{Impulse response analysis}

Figure 6 indicates that a positive domestic demand shock in the United States raises real personal consumption, the industrial production of manufactured goods and the NACTI on impact. The fact that the impact response of manufacturing output is clearly distinguishable from zero supports the interpretation that many companies hold inventories of raw materials and intermediate goods that allow them to raise production within a month in response to higher demand. The response of industrial production of manufactured goods peaks with a delay of one month, consistent with the initial demand boom being met in part with inventory drawdowns. Likewise, there is clear evidence of a positive impact response in the NACTI, 
consistent with an immediate increase in containerized imports. The NACTI response peaks with a delay of two months before slowly declining. The latter response also supports Humphreys, Maccini and Schuh's (2001) point that the positive response of U.S. input inventories to demand shocks is particularly important in the durable goods industries.

A demand shock not driven by domestic consumer demand, labeled a shock to the foreign demand for manufactured goods in Figure 6, causes a slowly declining increase in the industrial output of manufactured goods that peaks on impact. It is also associated with a persistent increase in the NACTI, whose response peaks with a delay of two months. Real personal goods consumption increases only with a substantial delay and the response is small and only imprecisely estimated. This makes sense, since one would not expect employment or the real wage to respond immediately.

Finally, an unexpected decline in container market frictions causes a blip in the NACTI in the impact period that is partially reversed in the next month and then gradually tapers off. Unexpected reductions in frictions also stimulate real personal consumption and the industrial production of manufactured goods in the United States. This result is consistent with the growing importance of global supply chains in manufacturing and the importance of imported consumer goods. It also is indicative of a tight link from container shipping to inventories. An unexpected delay in the container shipping of raw materials and intermediate products, for example, causes a drawdown in manufacturing firms' input inventories and ultimately a decline in their output inventories, while a delay in the delivery of finished products causes a drawdown in inventories for sale and ultimately of sales. ${ }^{11}$

\subsection{What is driving the variability of the VAR data?}

Table 6 shows that on average over the estimation period $50 \%$ of the variation in real

\footnotetext{
${ }^{11}$ Further analysis of the comovement between inventories and sales can be found in Herrera, Murtashazvili and Pesavento (2008).
} 
personal consumption relative to trend was driven by domestic demand shocks, only $11 \%$ by foreign demand shocks, but $38 \%$ by shocks in the container shipping market. In contrast, only $29 \%$ of the variability in U.S. industrial production of manufactured goods (relative to trend) is explained by frictions in the container market, with domestic demand shocks accounting for $34 \%$ and foreign demand shocks for U.S. manufactured goods explaining $38 \%$. Finally, $72 \%$ of the variation of the NACTI is explained by container-market related shocks, compared with only $17 \%$ by domestic demand shocks and $12 \%$ by foreign shocks to the demand for U.S. manufactures, suggesting that the feedback from the container market to the U.S. economy is quantitatively more important than the feedback in the reverse direction.

We now turn to the question of how much each of these shocks on its own cumulatively contributed to the variation in the model variables during the Great Recession of 2007-09 and during the COVID-19 Recession of 2020-21, controlling for variation in the other structural shocks. Such historical decompositions may be constructed, as discussed in Kilian and Lütkepohl (2017), given the Bayes estimate of the structural VAR model. In constructing the historical decomposition, we discard the first 144 fitted values of the data to eliminate the transition dynamics.

\subsection{A tale of two recessions}

Figure 7 helps compare the determinants of the decline in the NACTI during these two recessions. The first two panels show that the decline in 2008-09 caused by the cumulative effect of domestic demand shocks started several months earlier than the corresponding decline caused by foreign demand shocks, consistent with the housing and financial crisis in

the United States being the epicenter of this recession. Foreign demand shocks started adding to this decline in April 2008, causing a much steeper decline by 2009 than domestic shocks alone would have. The foreign-demand driven recovery started only in the second half of 2009 and, in fact, was complete only by 2014, consistent with the effects from the financial 
crisis being highly persistent. The drop in North American container trade was reinforced in late 2008 and early 2009 by increased frictions in the container market not caused by the slowdown in global demand. A likely contributing factor was the tightening market for trade credit (see. e.g., Asmundson, Dorsey, Khachatryan, Niculcea and Saito 2011; Chor and Manova 2012). Pricing for trade finance products became more expensive and there were concerns about counterparty risks which hindered international trade. Another likely explanation is importers not taking ownership of cargo, given low demand and high storage costs.

Whereas the onset of the Great Recession in the North American container market was gradual, that of the COVID-19 Recession in 2020 was much more sudden. Figure 7 shows that as late as early 2020, the cumulative effect of domestic demand shocks drove up container trade. When the recession started in March 2020, the drop in container trade was abrupt. Unlike during the Great Recession, foreign demand shocks made almost no contribution to this decline. However, this recession was preceded by a sizable decline in the NACTI that started in early 2019 already, indicating growing frictions in the container market, as trade tensions under the Trump administration and high policy uncertainty in 2019 undermined growth in global merchandise trade. UNCTAD (2020) reports that trade volumes expanded by only $0.5 \%$ in 2019 , down from $2.8 \%$ in 2018 , and growth in global container port traffic decelerated to $2 \%$, down from $5.1 \%$ in 2018 . These frictions worsened in early 2020, as the pandemic spread first in China and then in the rest of the world, with lockdowns disrupting global supply chains and reducing the volume of container shipping. Moreover, the use of larger and more highly utilized container vessels in response to the crisis, along with new working protocols at ports and a shortage of dock workers, necessitated longer storage times for containers at the yard. Another concern was importers not taking ownership of cargo, given low demand and high storage costs (see Notteboom, Pallis and Rodrigue 2021). 
While these points have been documented anecdotally, our structural model for the first time quantifies these effects.

Starting in May 2020, these frictions began to recede, in part through the increased use of automation in ports and in part because supply disruptions in China, in particular, were resolved. Container trade began to accelerate. In June 2020, foreign demand started exerting upward pressure on the NACTI and in July 2020, domestic demand shocks added to this pressure. Whereas the foreign demand component of the NACTI by early 2021 had surpassed its pre-pandemic level, the domestic demand driven component remained far below that benchmark. Much of the observed increase in the NACTI in late 2020 and early 2021, which suggests that North American container trade is almost recovered from the COVID-19 crisis, appears driven by lower frictions in the container shipping market rather than a recovery of U.S. import and export demand.

Figure 8 shows a very similar pattern for the evolution of U.S. industrial production of manufactured goods. The main difference is that the effect of shocks to container market frictions on industrial manufacturing output is much more muted and, overall, the recovery in production is weaker than in container trade. The results for real personal consumption in Figure 9 reinforce our earlier point that real personal consumption was relatively insensitive to domestic demand shocks during the Great Recession, but responded strongly during 202021. The combined effect of foreign shocks on U.S. real personal consumption averaged out during the Global Financial Crisis. In contrast, foreign demand shocks left real personal consumption largely unaffected during 2020-21. Shocks to container market frictions initially

slightly lowered U.S. real personal consumption in 2020, but stimulated it later in 2020 and in early 2021, allowing it to recover to near its pre-pandemic level (relative to trend).

\subsection{Disaggregate Real Personal Consumption Measures}

Figure 10 reexamines the results for real personal consumption based on an alternative VAR 
model specification including real personal consumption of goods. The focus is on the recovery from the Covid-19 pandemic. All results are obtained by replacing the real consumption measure in the baseline model by alternative consumption measures. The first column of Figure 10 shows that the drop in personal goods consumption in early 2020 was much more muted than for overall personal consumption, consistent with the view that consumers cut back on the consumption of services more than on goods consumptions and even raised their consumption of goods over time. By all accounts, by mid-2020, the domestic demand component of real personal goods consumption had returned to its prepandemic level. Notwithstanding some volatility in late 2020, it ultimately continued to rise relative to trend in early 2021.

Further disaggregating these results into durable and nondurable goods consumption shows that the domestic demand component of the consumption of durables dropped much more in early 2020 than that of overall goods consumption. This drop is less likely to reflect a drop in latent consumer demand than the inability of manufacturers to deliver durable goods items such as furniture, fridges or other household appliances in a timely manner, which prevented that demand from being realized. In contrast, the domestic demand component of the consumption of nondurables spiked in March, when consumers stocked up on essentials such as food and cleaning products, and declined only modestly in mid-year. Moreover, there is evidence for a stronger recovery of foreign demand for durables than nondurables starting in the second half of 2020. Notwithstanding these nuances, the pattern over time is similar for all three historical decompositions.

\subsection{What we can learn from the NACTI about the U.S. recovery in 2020-21?}

Table 7 summarizes the cumulative decline in percentage points in selected log-linearly detrended macroeconomic aggregates from February 2020 to April 2020, their recovery from April 2020 to March 2021, and their overall cumulative change since February 2020. It also 
shows in percent the extent to which the contraction of early 2020 has been made up since April 2020. In addition, Table 7 reports for each series to what extent these changes are driven by each of the three structural shocks in the VAR model, allowing an economic interpretation of the observed changes.

The central question of interest is to what extent U.S. real personal consumption has recovered relative to its trend. Table 7 shows that detrended real consumption as of March 2021 has recovered to 94\% of its level in February 2020, right before the pandemic slowed the U.S. economy. This evidence may suggest that domestic demand has all but recovered, but closer examination reveals that the domestic demand component has only recovered to $78 \%$. The difference is accounted for by strong tailwinds from positive foreign demand shocks and especially from favorable container market shocks.

The alternative models introduced in Section 4.4 allow us to examine more specifically the recovery in real personal goods consumption. Consistent with anecdotal evidence that consumers persisted in buying goods throughout the pandemic, even as they curtailed purchases of many services, Table 7 shows that goods consumption not only was much less susceptible to the downturn, but has been booming as of late. By March 2021, it had recovered by $191 \%$, compared with only $94 \%$ for overall consumption. While other shocks also contributed to this expansion, it is mainly driven by the domestic demand component, which alone propels goods consumption to $150 \%$ percent above pre-pandemic levels. Table 7 also shows results for durable and nondurable goods consumption, which recovered to $190 \%$ and $184 \%$ of pre-pandemic levels, respectively, again driven mainly by a recovery of domestic demand. The recovery of durables consumption was helped by reduced frictions in container shipping and higher foreign demand for U.S. manufactured goods, whereas that of nondurables was not.

Compared to real personal consumption, the recovery in detrended U.S. 
manufacturing output to $87 \%$ or pre-pandemic levels has been somewhat slower. As in the case of personal consumption, this recovery obscures that the domestic demand component of manufacturing output only has recovered to $57 \%$. The difference is accounted for by favorable foreign demand and container market shocks. Put differently, the recovery in domestic demand underlying the recovery of personal consumption has benefitted foreign producers more than domestic manufacturers. This evidence also underscores that the growth in trade volumes may be faster than changes in economic activity, adding to recent evidence that trade growth need not be proportionate to overall economic growth (see, e.g., IRC Trade Task Force 2016). We conclude that the recovery of domestic demand in the United States, as of March 2021, appears slower than the raw data for personal consumption expenditures and manufacturing output may suggest. In part, this weakness reflects continued low demand for consumer services, driven by Covid-19 related restrictions. As these restrictions ease, one would expect the recovery of domestic demand to accelerate.

\section{Conclusion}

It is widely recognized among policy makers that global supply chains and trade in consumer goods and other manufactured goods is essential for understanding the business cycle. Much of this trade involves container shipping, yet we are not aware of any quantitative work on how sea-borne container trade in particular contributes to economic activity. One of the challenges has been that most container trade statistics are annual and hence unsuitable for business cycle analysis. Existing monthly indices of container trade only date back to 2007 . In this paper, we developed a new monthly index of the volume of container shipping to and from the United States and Canada that is available as far back as January 1995. We illustrated how this index may be used to shed light on the determinants of U.S. manufacturing output and real personal consumption during the Great Recession as well as the COVID-19 Recession. 
Incorporating the container trade index into simple, yet economically plausible structural macroeconomic VAR model allowed us to identify shocks to domestic U.S. demand as well as foreign demand for U.S. manufactured goods. We used this model to study the determinants of the COVID-19 Recession in particular and to quantify the strength and pattern of the economic recovery since April 2020. We not only examined how frictions in container shipping affect the U.S. economy, but also examined the link from the U.S. economy to the volume of North American container shipping. Our results are of interest both to macroeconomists concerned with the state of the U.S. economy and the recovery from the COVID-19 Recession and to shipping market analysts interested in the dependence of container freight volumes on the state of the U.S. economy.

\section{References}

Asmundson, I., Dorsey, T., Khachatryan, A., Niculcea, I., and M. Saito (2011), “Trade and Trade Finance in the 2008-09 Financial Crisis," IMF Working Paper No. 11/16. https://www.imf.org/external/pubs/ft/wp/2011/wp1116.pdf

Behrens, K., and P.M. Picard (2011), “Transportation, Freight Rates, and Economic Geography," Journal of International Economics, 85, 280-291. https://doi.org/10.1016/j.jinteco.2011.06.003

Bernhofen, D.M., El-Sahli, Z., and R. Kneller (2016), "Estimating the Effects of the Container Revolution on World Trade," Journal of International Economics, 98, 3650. https://doi.org/10.1016/j.jinteco.2015.09.001

Chor, D., and K. Manova (2012), "Off the Cliff and Back? Credit Conditions and International Trade during the Global Financial Crisis," Journal of International Economics, 87, 117-133. https://doi.org/10.1016/j.jinteco.2011.04.001

Cosar, A.K., and B. Demir (2018), "Shipping Inside the Box: Containerization and Trade," Journal of International Economics, 114, 331-345. 
https://doi.org/10.1016/j.jinteco.2018.07.008

Congressional Budget Office (2006), "The Economic Costs of Disruptions in Container

Shipping," Report to the Permanent Subcommittee on Investigations, Committee on Homeland Security and Governmental Affairs, United States Senate.

https://www.cbo.gov/publication/17680

Döhrn, R. (2019), “Sieben Jahre RWI/ISL-Containerumschlag-Index - ein Erfahrungsbericht. Wirtschaftsdienst, 99, 224-226. https://doi.org/10.1007/s10273-019-2422-z

Döhrn, R. and S. Maatsch (2012), "Der RWI/ISL-Containerumschlag-Index - Ein neuer Frühindikator für den Welthandel," Wirtschaftsdienst, 92, 352-354. https://doi.org/10.1007/s10273-012-1387-y

Flaaen, A., and J. Pierce (2019), "Disentangling the Effects of the 2018-2019 Tariffs on a Globally Connected U.S. Manufacturing Sector,” Finance and Economics Discussion Series No. 2019-086, Federal Reserve Board. https://doi.org/10.17016/FEDS.2019.086

Herrera, A.M., Murtashazvili, I., and E. Pesavento (2008), “The Comovement between Inventory Investment and Sales: Higher and Higher," Economics Letters, 99, 155-158. https://doi.org/10.1016/j.econlet.2007.06.037

Hummels, D. (2007), "Transportation Costs and International Trade in the Second Era of Globalization," Journal of Economic Perspectives, 21, 131-154. https://doi.org/10.1257/jep.21.3.131

Humphreys, B.R., Maccini, L.J., and S. Schuh (2001). "Input and Output Inventories," Journal of Monetary Economics 47, 347-375. https://doi.org/10.1016/s0304-3932(01)00046-0

IRC Trade Task Force (2016), "Understanding the weakness in global trade: what is the new 
normal?” Occasional Paper Series No. 178, European Central Bank. https://www.ecb.europa.eu/pub/pdf/scpops/ecbop178.en.pdf

Jeon, J. (2020), "Learning and Investment under Demand Uncertainty in Container

Shipping," RAND Journal of Economics, conditionally accepted.

Inoue, A., and L. Kilian (2021), “Joint Bayesian Inference about Impulse Responses in VAR Models," Journal of Econometrics, forthcoming.

Ishikawa, J., and N. Tarui (2018), "Backfiring with Backhaul Problems: Trade and Industrial Policies with Endogenous Transport Costs," Journal of International Economics, 111, 81-98. https://doi.org/10.1016/j.jinteco.2017.12.004

Karlsson, S. (2013), "Forecasting Bayesian vector autoregressions," in: G. Elliott and A. Timmermann (eds.), Handbook of Economic Forecasting, 2, Amsterdam:

North-Holland, 2013, 791-897. https://doi.org/10.1016/B978-0-444-62731-5.00015-4

Kilian, L., and H. Lütkepohl (2017), Structural Vector Autoregressive Analysis, Cambridge University Press. https://doi.org/10.1017/9781108164818

Kilian, L., and X. Zhou (2018), "Modeling Fluctuations in the Global Demand for Commodities," Journal of International Money and Finance, 88, 54-78. https://doi.org/10.1016/j.jimonfin.2018.07.001

Lee, C.Y., and D.P. Song (2017), “Ocean Container Transport in Global Supply Chains: Overview and Research Opportunities," Transportation Research Part B: Methodological, 95, 442-474. https://doi.org/10.1016/j.trb.2016.05.001

Notteboom, T., Pallis, T., and J.P. Rodrigue (2021), "Disruptions and Resilience in Global Container Shipping and Ports: The COVID-19 Pandemic versus the 2008-2009 Financial Crisis. Maritime Economics and Logistics. https://doi.org/10.1057/s41278-020-00180-5

OECD (2020), “Coronavirus: The World Economy At Risk," Interim Economic Assessment, 
March. https://www.oecd.org/berlin/publikationen/Interim-Economic-Assessment-2March-2020.pdf

UNCTAD (2020), Review of Maritime Transport, United Nations, Geneva, Switzerland, https://unctad.org/system/files/official-document/rmt2020 en.pdf.

Wen, Y. (2011), “Input and Output Inventory Dynamics," American Economic Journal:

Macroeconomics 3, 181-212. https://doi.org/10.1257/mac.3.4.181

Wong, W.F. (2020), “The Round-Trip Effect: Endogenous Transport Costs and International Trade," American Economic Journal: Applied Economics, conditionally accepted. 
Table 1: Container Traffic at Major North American Ports in 2018

\begin{tabular}{lcc}
\hline Sea Port & TEU in 2018 & Percentage \\
\hline Long Beach & $8,091,029$ & $17 \%$ \\
Los Angeles & $9,458,749$ & $20 \%$ \\
Oakland & $2,546,357$ & $5 \%$ \\
Seattle/Tacoma & $3,797,629$ & $8 \%$ \\
New York/New Jersey & $7,179,792$ & $15 \%$ \\
Virginia & $2,855,914$ & $6 \%$ \\
Charleston & $2,316,255$ & $5 \%$ \\
Savannah & $4,351,976$ & $9 \%$ \\
Houston & $2,699,850$ & $6 \%$ \\
\hline U.S. Total & $43,297,551$ & $89 \%$ \\
\hline Vancouver & $2,396,449$ & $51 \%$ \\
Montreal & $1,679,351$ & $25 \%$ \\
\hline Canadian Total & $5,075,800$ & $76 \%$ \\
\hline
\end{tabular}

NOTES: TEU stands for twenty-foot equivalent container. All North American ports handling more than 1.5 million TEUs of traffic in 2018 are included.

Table 2: Cross-Auto-Correlations, Linearly Detrended Data, 2007.1-2021.3

\begin{tabular}{lccccccc}
\hline \hline $\begin{array}{l}\text { World Industrial } \\
\text { Production }\end{array}$ & $t-3$ & $t-2$ & $t-1$ & $t$ & $t+1$ & $t+2$ & $t+3$ \\
\hline RWI-ISL & 0.705 & 0.786 & 0.865 & $\mathbf{0 . 8 8 2}$ & 0.850 & 0.804 & 0.715 \\
& & & & & & & \\
\hline
\end{tabular}

NOTES: The data sources are described in the text. The maximum is shown in bold.

Table 3: Cross-Auto-Correlations, Growth Rates, 2007.2-2021.3

\begin{tabular}{lccccccc}
\hline $\begin{array}{l}\text { World Industrial } \\
\text { Production }\end{array}$ & $t-3$ & $t-2$ & $t-1$ & $t$ & $t+1$ & $t+2$ & $t+3$ \\
\hline RWI-ISL & 0.021 & $\mathbf{0 . 4 3 1}$ & 0.345 & 0.090 & 0.321 & 0.065 & 0.019
\end{tabular}

NOTES: The data sources are described in the text. The maximum is shown in bold.

Table 4: Cross-Auto-Correlations, Linearly Detrended Data, 2007.1-2021.3

\begin{tabular}{lccccccc}
\hline \hline $\begin{array}{l}\text { U.S. IP } \\
\text { Manufacturing }\end{array}$ & $t-3$ & $t-2$ & $t-1$ & $t$ & $t+1$ & $t+2$ & $t+3$ \\
\hline NACTI & 0.468 & 0.563 & 0.629 & 0.673 & $\mathbf{0 . 6 7 9}$ & 0.641 & 0.594 \\
\hline $\begin{array}{l}\text { Real personal goods } \\
\text { consumption }\end{array}$ & $t-3$ & $t-2$ & $t-1$ & $t$ & $t+1$ & $t+2$ & $t+3$ \\
\hline NACTI & 0.586 & 0.671 & 0.695 & $\mathbf{0 . 7 2 9}$ & 0.669 & 0.610 & 0.564 \\
\hline NOTES: The data sources are described in the text. The maximum is shown in bold. &
\end{tabular}


Table 5: Cross-Auto-Correlations, Growth Rates, 2007.2-2021.3

\begin{tabular}{lccccccc}
\hline \hline $\begin{array}{l}\text { U.S. IP } \\
\text { Manufacturing }\end{array}$ & $t-3$ & $t-2$ & $t-1$ & $t$ & $t+1$ & $t+2$ & $t+3$ \\
\hline NACTI & -0.050 & 0.089 & 0.157 & 0.076 & $\mathbf{0 . 2 1 3}$ & 0.034 & -0.096 \\
\hline $\begin{array}{l}\text { Real personal goods } \\
\text { consumption }\end{array}$ & $t-3$ & $t-2$ & $t-1$ & $t$ & $t+1$ & $t+2$ & $t+3$ \\
\hline NACTI & -0.033 & $\mathbf{0 . 1 9 9}$ & 0.072 & 0.017 & 0.140 & -0.057 & -0.097 \\
\end{tabular}

NOTES: The data sources are described in the text. The maximum is shown in bold.

Table 6: VAR Variance decomposition, 1995.1-2021.3

\begin{tabular}{|l|c|c|c|}
\hline Variable & $\begin{array}{c}\text { Domestic demand } \\
\text { shock }\end{array}$ & $\begin{array}{c}\text { Foreign demand } \\
\text { shock }\end{array}$ & $\begin{array}{c}\text { Container market } \\
\text { shock }\end{array}$ \\
\hline $\begin{array}{l}\text { Real personal } \\
\text { consumption }\end{array}$ & $50.3 \%$ & $11.3 \%$ & $38.4 \%$ \\
\hline $\begin{array}{l}\text { U.S. Industrial } \\
\text { production: } \\
\text { Manufacturing }\end{array}$ & $33.8 \%$ & $37.5 \%$ & $28.7 \%$ \\
\hline NACTI & $16.8 \%$ & $11.5 \%$ & $71.7 \%$ \\
\hline
\end{tabular}

NOTES: Estimates based on the Bayes estimate of the impulse responses in Figure 6. 
Table 7: Determinants of the U.S. COVID-19 Recession and Recovery in Detrended Real Personal Consumption and Manufacturing Output

\begin{tabular}{|c|c|c|c|c|}
\hline & \multicolumn{3}{|c|}{ Percentage points } & \multirow[b]{2}{*}{$\begin{array}{l}\text { Recovery } \\
\text { since } \\
2020.2\end{array}$} \\
\hline & $\begin{array}{l}\text { Cumulative } \\
\text { Decline } \\
\text { 2020.2-2020.4 }\end{array}$ & $\begin{array}{l}\text { Cumulative } \\
\text { Recovery } \\
\text { 2020.4-2021.3 }\end{array}$ & $\begin{array}{l}\text { Net Cumulative } \\
\text { Change } \\
2020.2-2021.3\end{array}$ & \\
\hline $\begin{array}{l}\text { U.S. real personal } \\
\text { consumption }\end{array}$ & -20.2 & 19.0 & -1.1 & $94 \%$ \\
\hline $\begin{array}{l}\text { Contribution of domestic } \\
\text { demand shock }\end{array}$ & -19.4 & 15.2 & -4.3 & $78 \%$ \\
\hline $\begin{array}{l}\text { Contribution of foreign } \\
\text { demand shock }\end{array}$ & -0.1 & 0.3 & 0.2 & $431 \%$ \\
\hline $\begin{array}{l}\text { Contribution of container } \\
\text { market friction shock }\end{array}$ & -0.7 & 3.6 & 2.9 & $524 \%$ \\
\hline $\begin{array}{l}\text { U.S. real total personal } \\
\text { goods consumption }\end{array}$ & -14.5 & 27.8 & 13.2 & $191 \%$ \\
\hline $\begin{array}{l}\text { Contribution of domestic } \\
\text { demand shock }\end{array}$ & -14.1 & 21.2 & 7.1 & $150 \%$ \\
\hline $\begin{array}{l}\text { Contribution of foreign } \\
\text { demand shock }\end{array}$ & 0.2 & 4.1 & 4.3 & $2260 \%$ \\
\hline $\begin{array}{l}\text { Contribution of container } \\
\text { market friction shock }\end{array}$ & -0.6 & 2.5 & 1.9 & $432 \%$ \\
\hline $\begin{array}{l}\text { U.S. real personal durables } \\
\text { only }\end{array}$ & -24.8 & 47.1 & 22.2 & $190 \%$ \\
\hline $\begin{array}{l}\text { Contribution of domestic } \\
\text { demand shock }\end{array}$ & -24.6 & 33.7 & 9.1 & $137 \%$ \\
\hline $\begin{array}{l}\text { Contribution of foreign } \\
\text { demand shock }\end{array}$ & 0.4 & 9.1 & 9.5 & N.A. \\
\hline $\begin{array}{l}\text { Contribution of container } \\
\text { market friction shock }\end{array}$ & -0.6 & 4.3 & 3.7 & $704 \%$ \\
\hline $\begin{array}{l}\text { U.S. real personal } \\
\text { nondurables only }\end{array}$ & -9.6 & 17.6 & 8.0 & $184 \%$ \\
\hline $\begin{array}{l}\text { Contribution of domestic } \\
\text { demand shock }\end{array}$ & -8.0 & 15.1 & 7.1 & $189 \%$ \\
\hline $\begin{array}{l}\text { Contribution of foreign } \\
\text { demand shock }\end{array}$ & -1.1 & 1.3 & 0.1 & $113 \%$ \\
\hline $\begin{array}{l}\text { Contribution of container } \\
\text { market friction shock }\end{array}$ & -0.5 & 1.2 & 0.8 & $272 \%$ \\
\hline $\begin{array}{l}\text { U.S. industrial production: } \\
\text { Manufacturing }\end{array}$ & -22.5 & 19.7 & -2.9 & $87 \%$ \\
\hline $\begin{array}{l}\text { Contribution of domestic } \\
\text { demand shock }\end{array}$ & -20.7 & 11.8 & -8.9 & $57 \%$ \\
\hline $\begin{array}{l}\text { Contribution of foreign } \\
\text { demand shock }\end{array}$ & -0.8 & 2.4 & 1.7 & $318 \%$ \\
\hline $\begin{array}{l}\text { Contribution of container } \\
\text { market friction shock }\end{array}$ & -1.1 & 5.5 & 4.4 & $502 \%$ \\
\hline
\end{tabular}

NOTES: Computations based on the historical decompositions shown in Figures 8-10. 


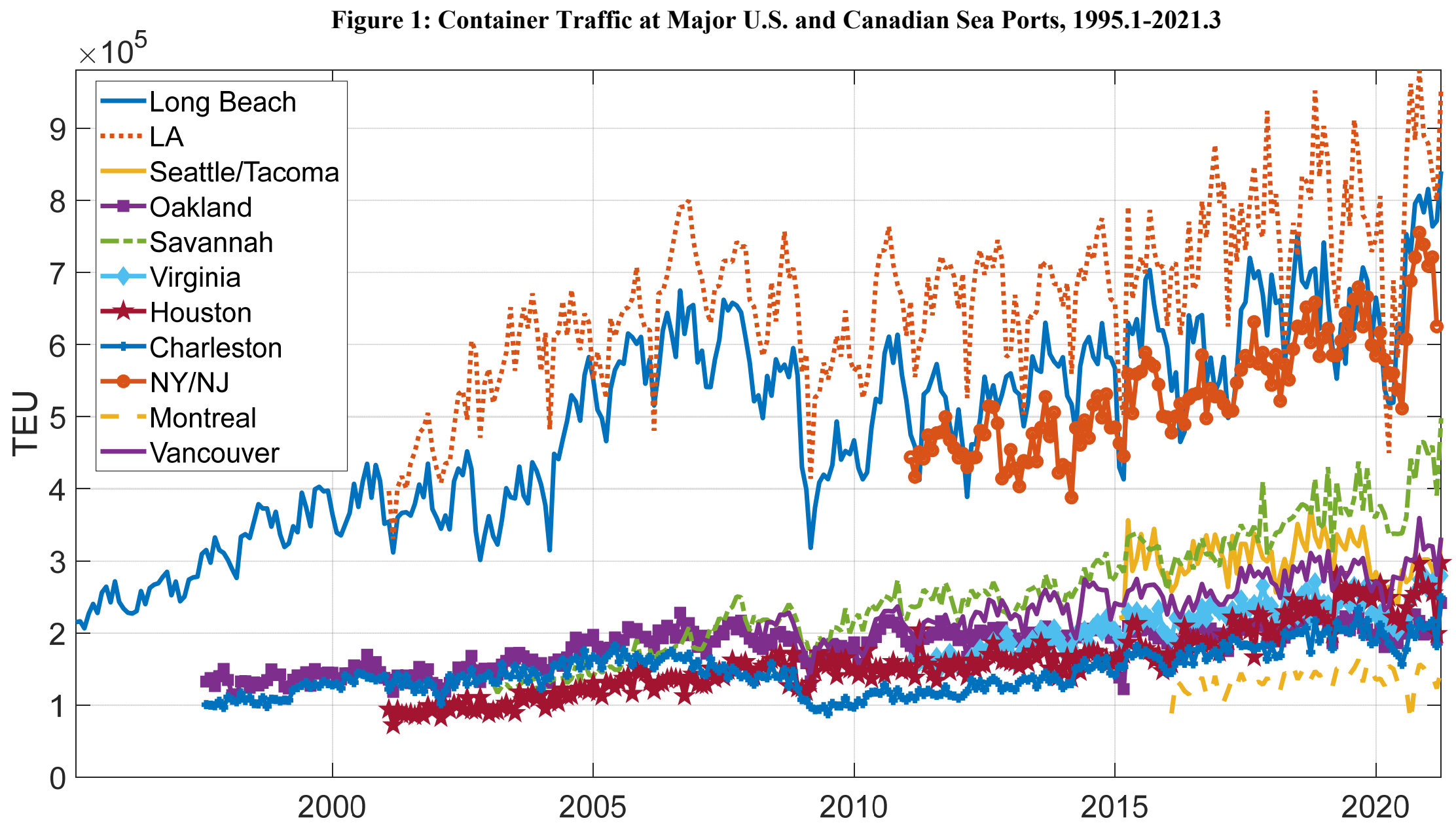

NOTES: TEU stands for twenty-foot equivalent container. All North American ports handling more than 1.5 million TEUs of traffic in 2018 are included. 
Figure 2: Indices of Container Trade, 1995.1-2021.3

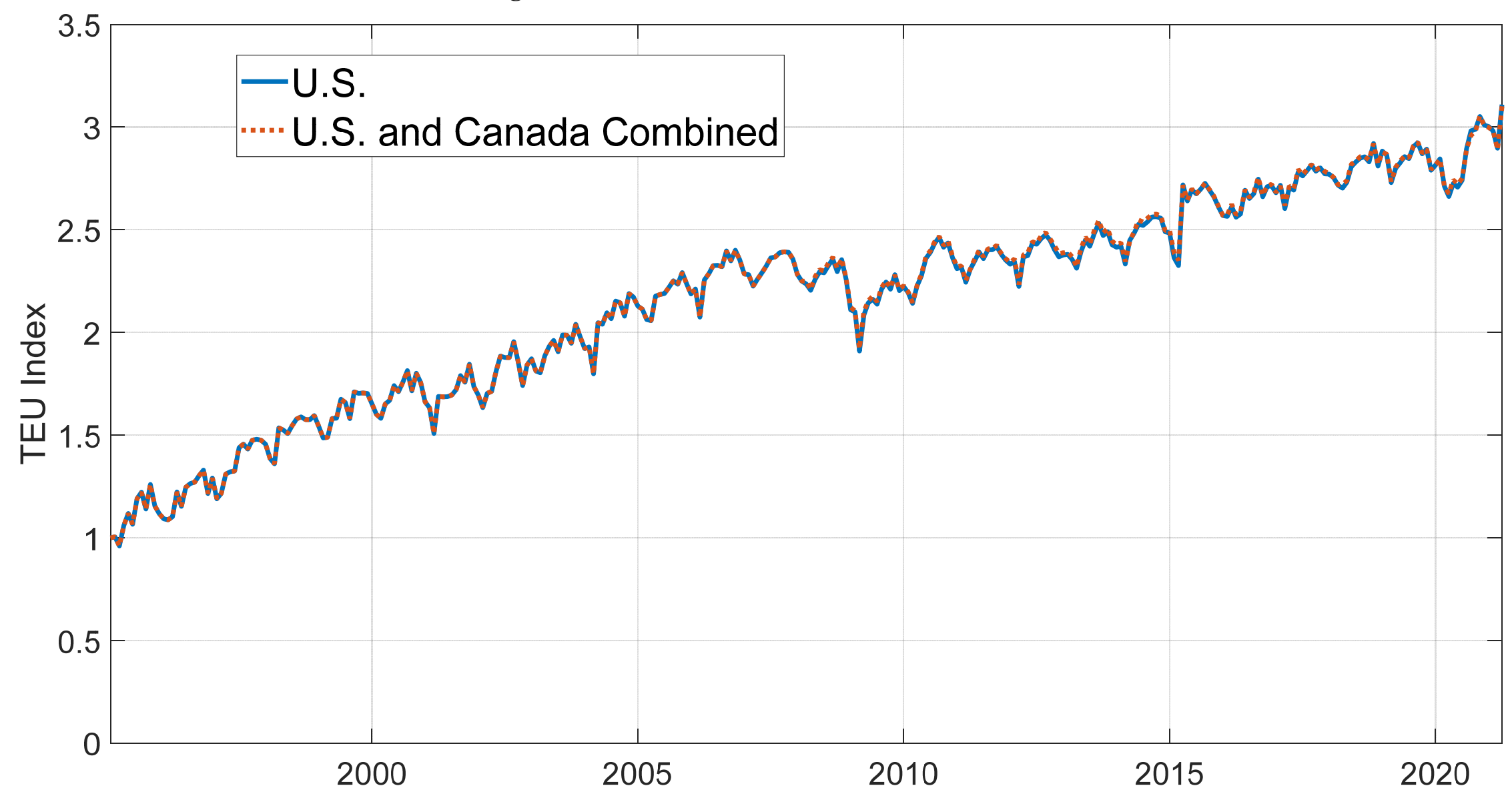

NOTES: Indices computed based on cumulating the growth rate of total TEU for all ports combined, for which TEU growth rates can be computed. Not seasonally adjusted. 
Figure 3: North American Container Trade Index (NACTI), 1995.1-2021.3

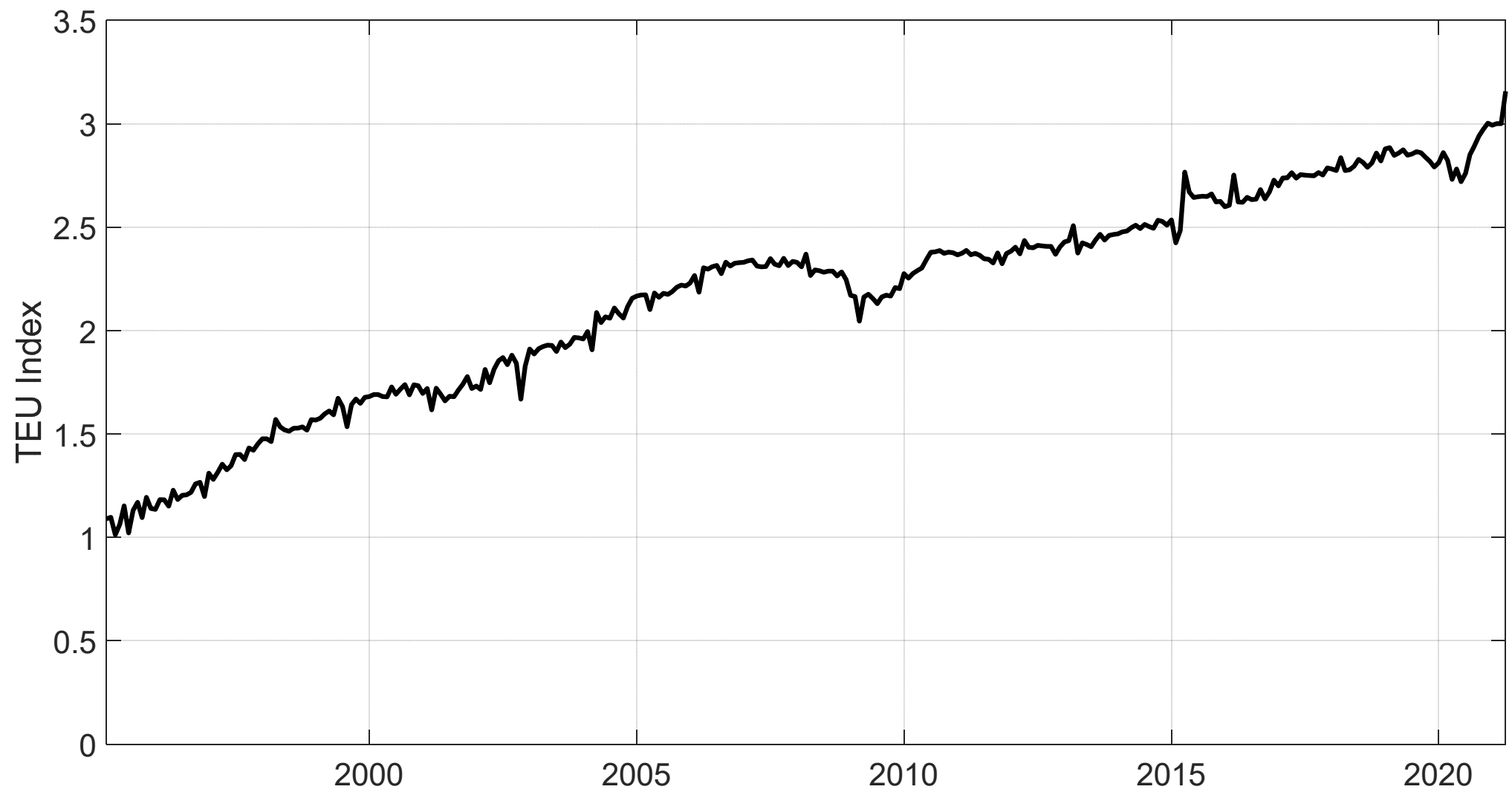

NOTES: TEU index for U.S. and Canada after removing seasonality with the MATLAB X-13 Toolbox for Seasonal Filtering. 
Figure 4: Linearly Detrended Container Trade Indices, 2007.1-2021.3

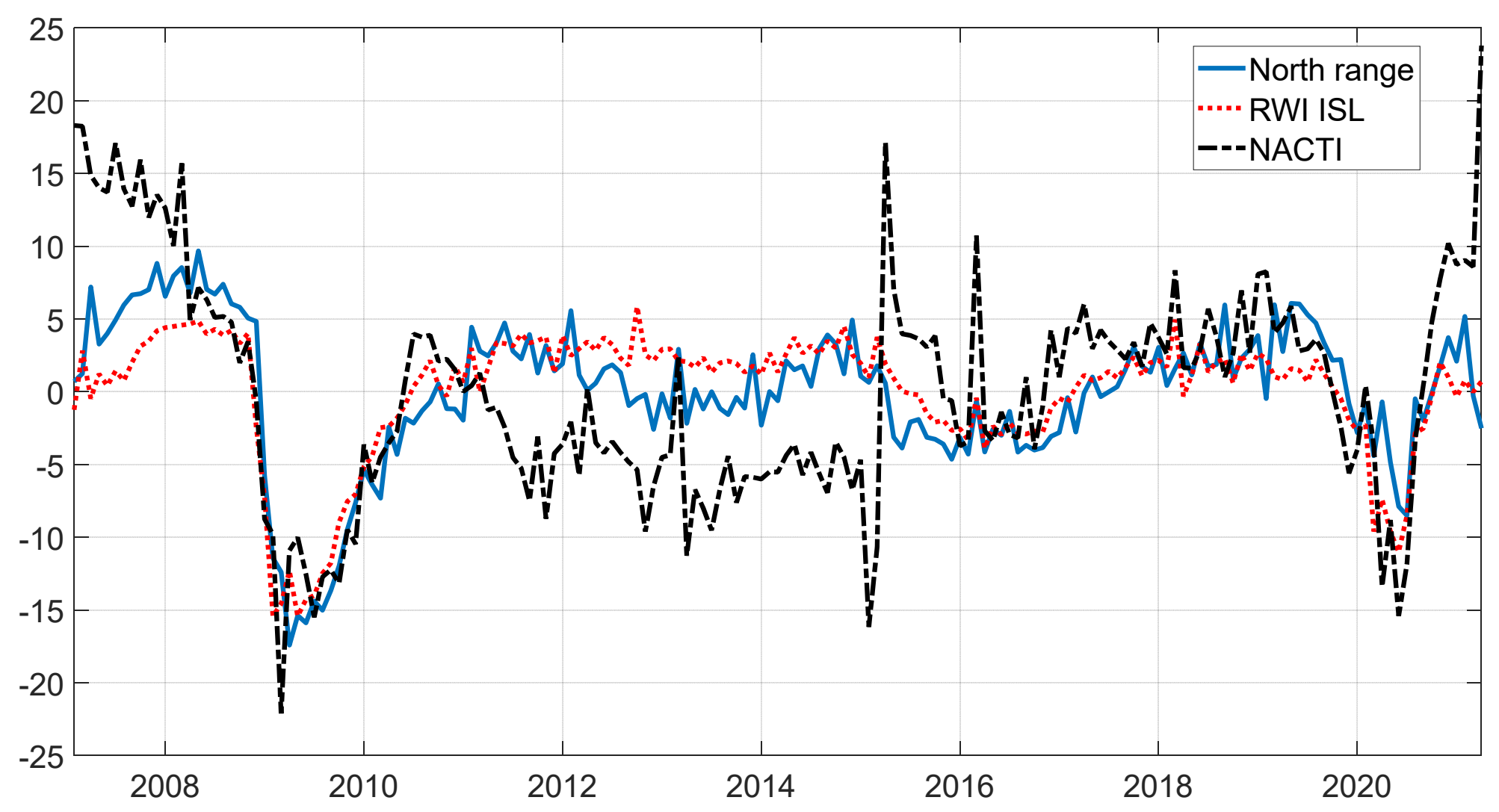

NOTES: The RWI/ISL index is a global container trade index, whereas the North range index is representative of container trade in central Europe. 
Figure 5: Linearly Detrended VAR Data, 1995.1-2021.3

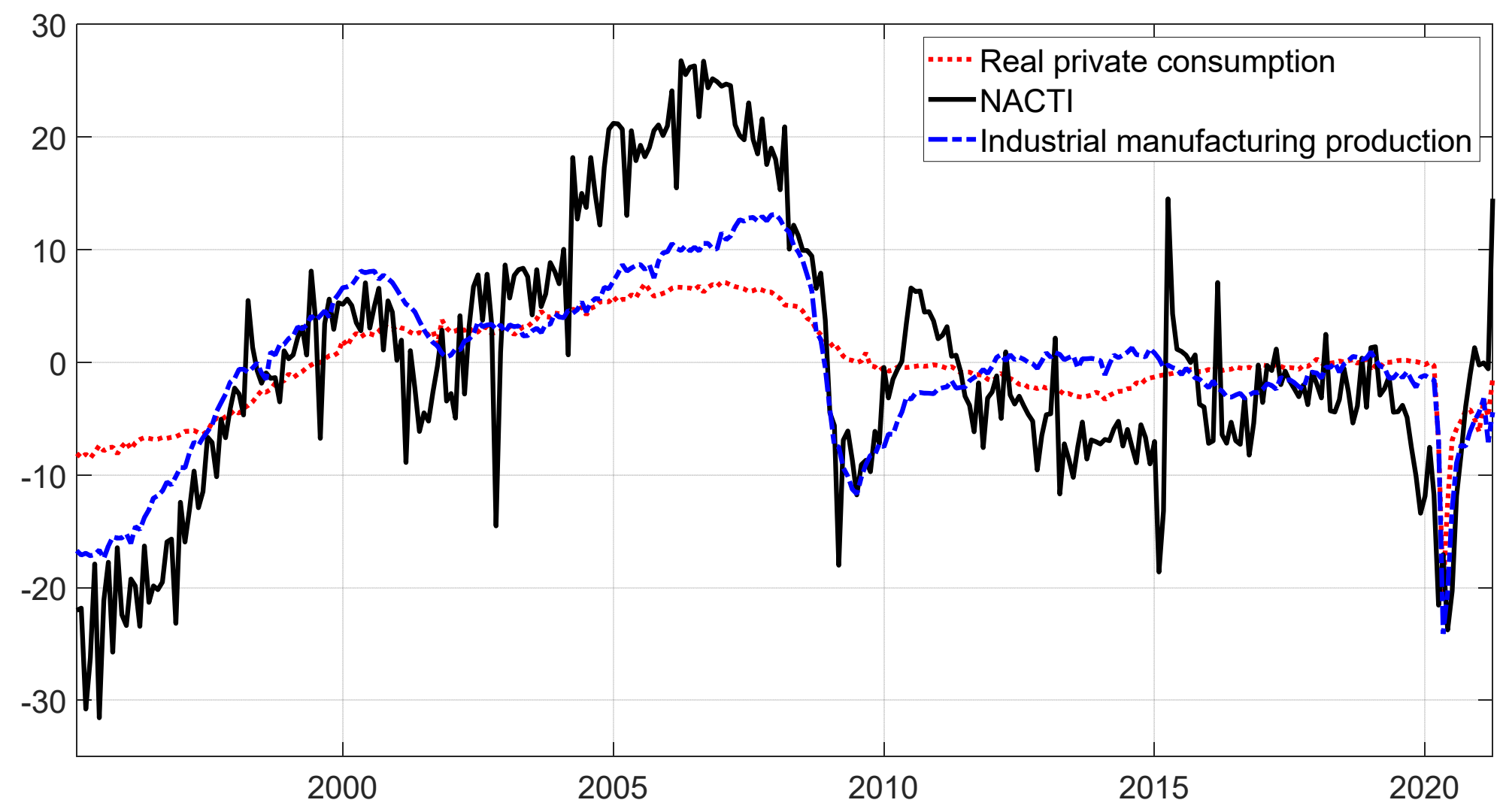


Figure 6: Impulse response estimates and 68\% joint credible sets, 1995.1-2021.3
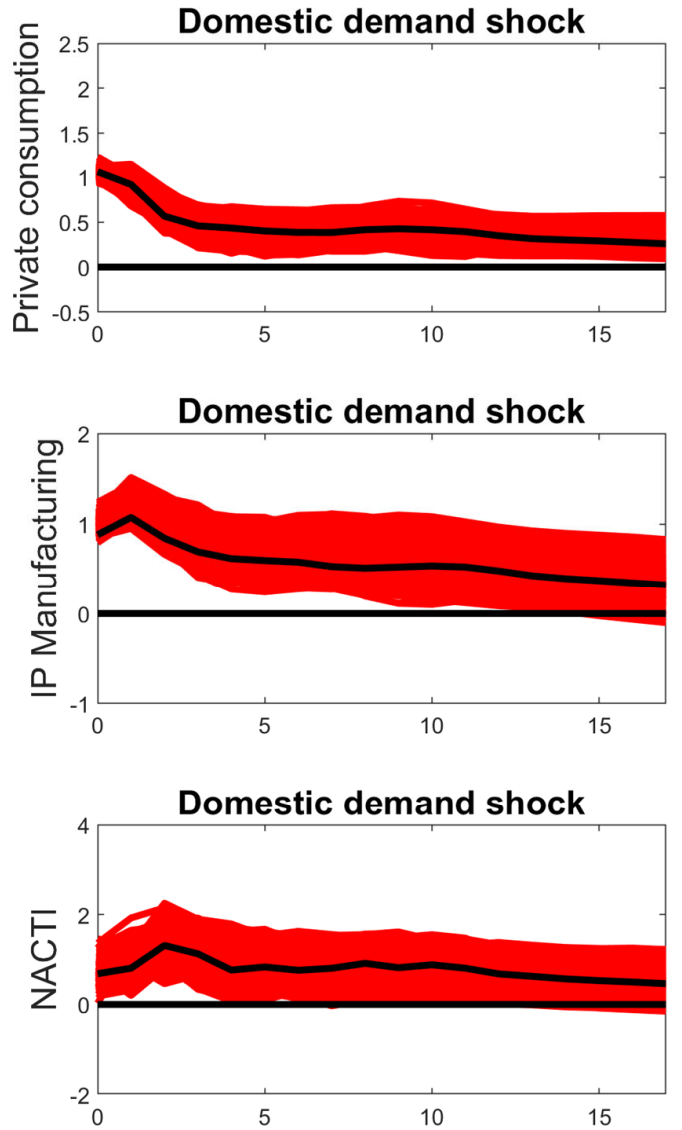

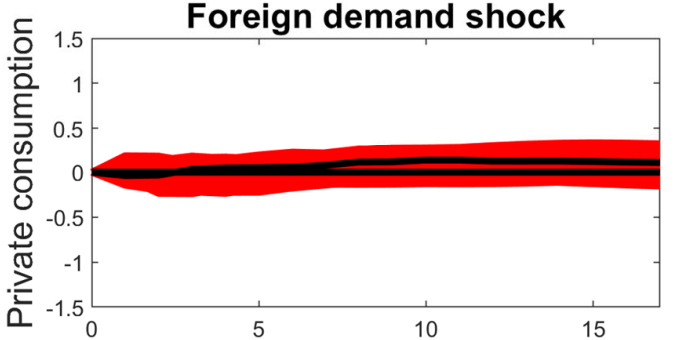

Foreign demand shock

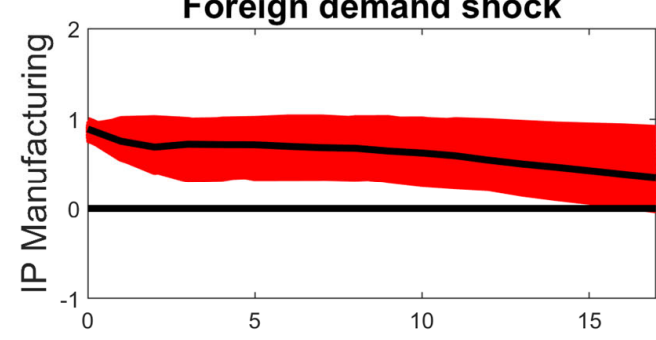

Foreign demand shock

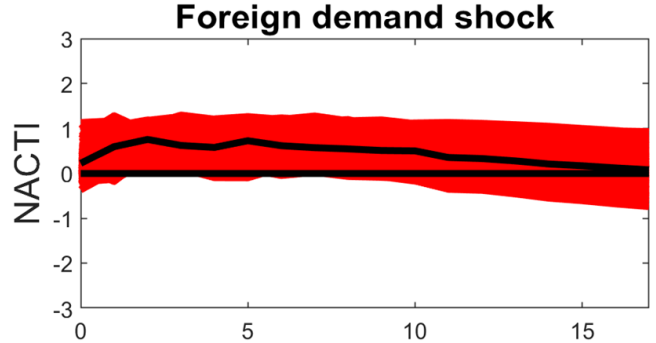

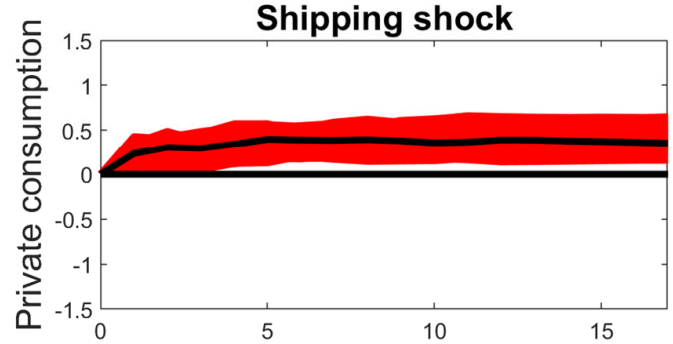

Shipping shock

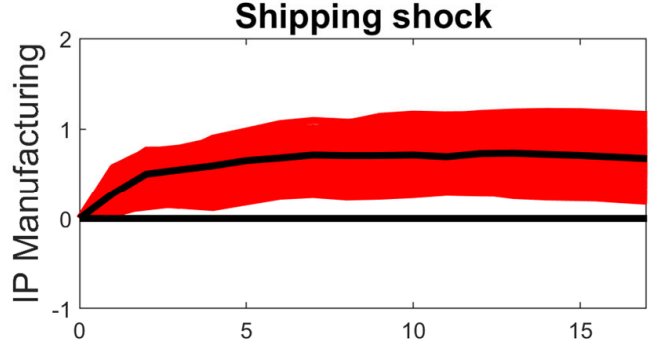

Shipping shock

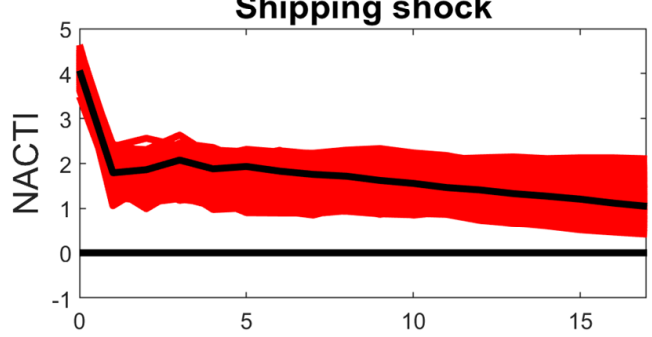

NOTES: The set of impulse responses shown in black is obtained by minimizing the absolute loss function in expectation over the set of admissible structural models, as discussed in Inoue and Kilian (2021). The responses in the corresponding joint credible set are shown in a lighter shade. 
Figure 7: Historical Decomposition of NACTI

2008.1-2010.6
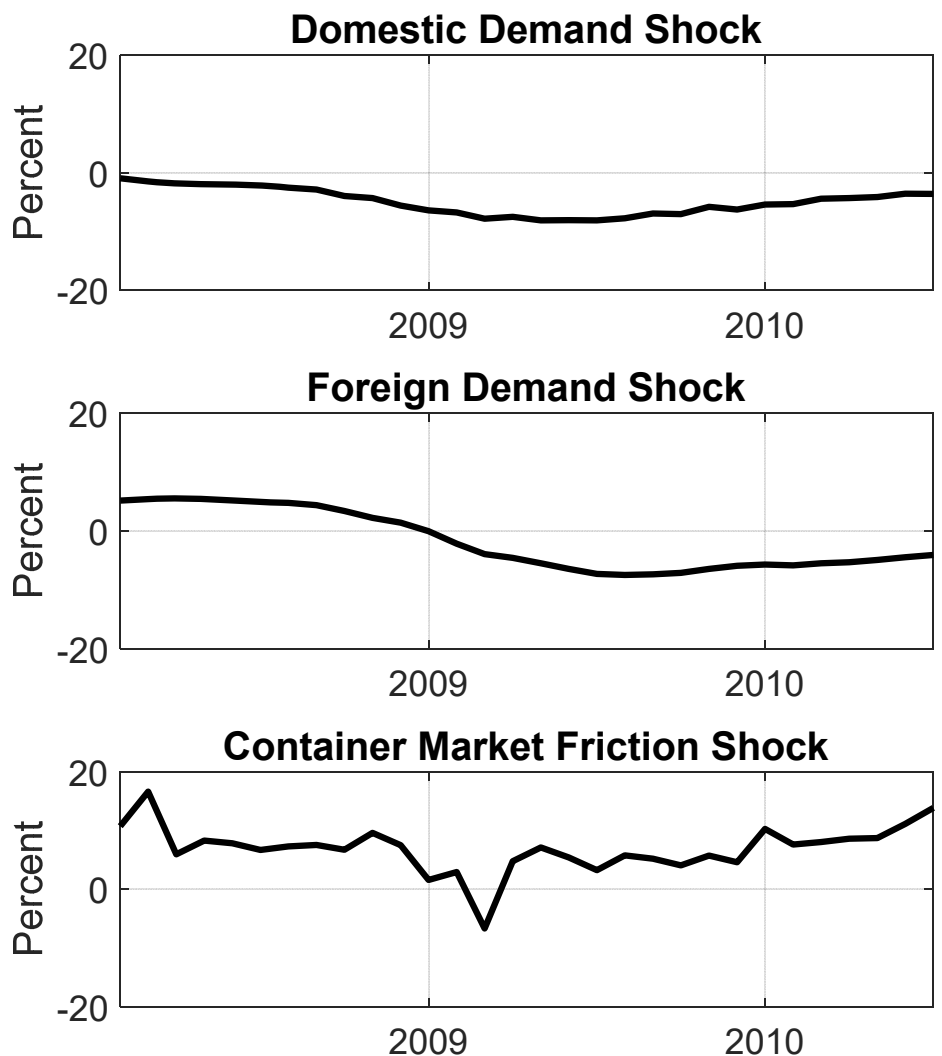

2019.1-2021.3

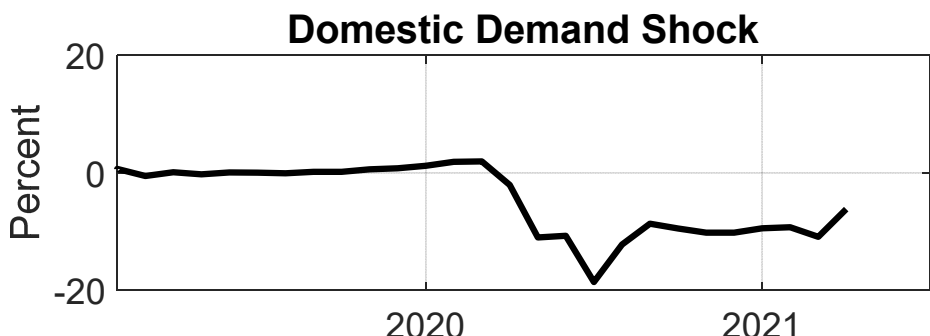

Foreign Demand Shock
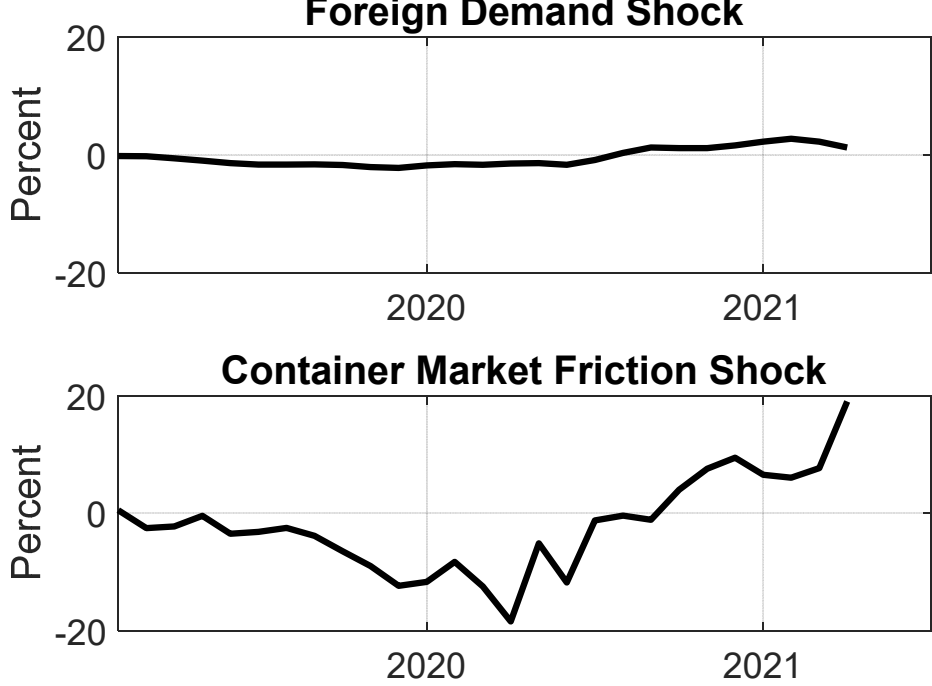

NOTES: Based on the cumulative effects of each shocks underlying the Bayes estimate of the impulse responses in Figure 5, while setting the other shock to zero. 
Figure 8: Historical Decomposition of U.S. Industrial Manufacturing Production

2008.1-2010.6

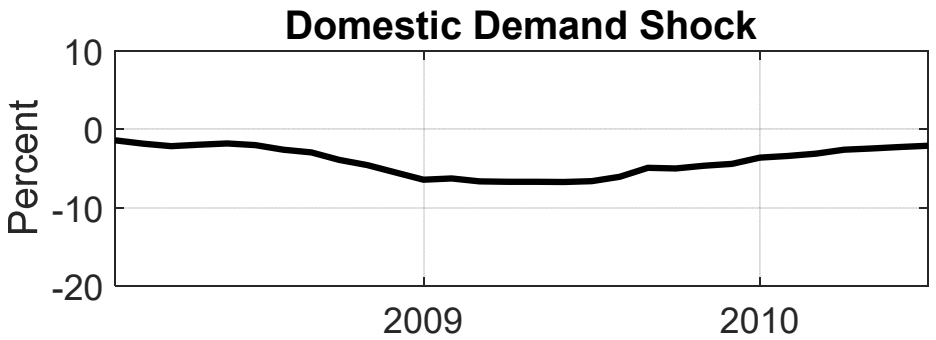

Foreign Demand Shock
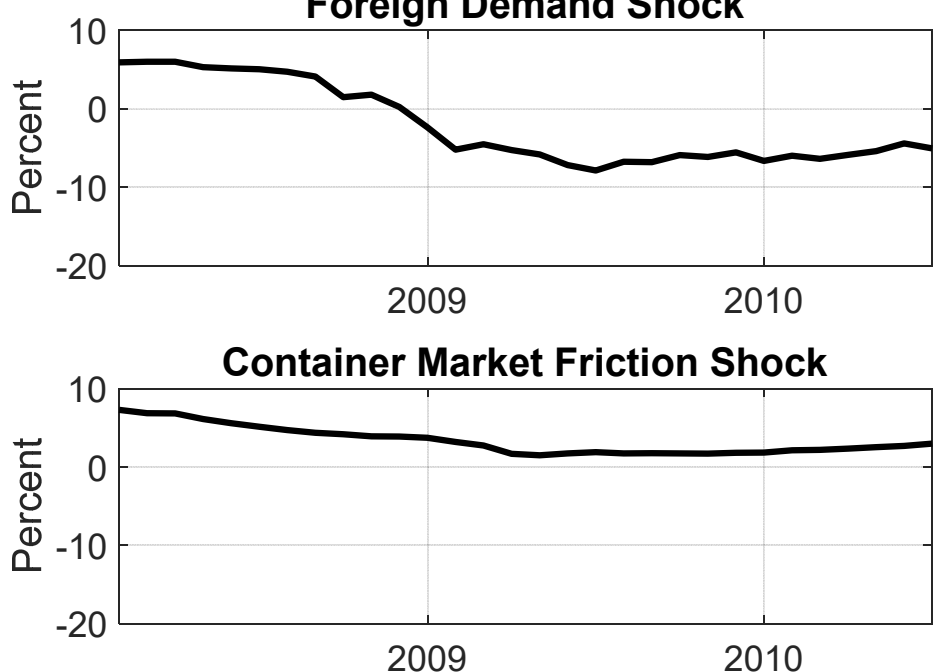

2019.1-2021.3

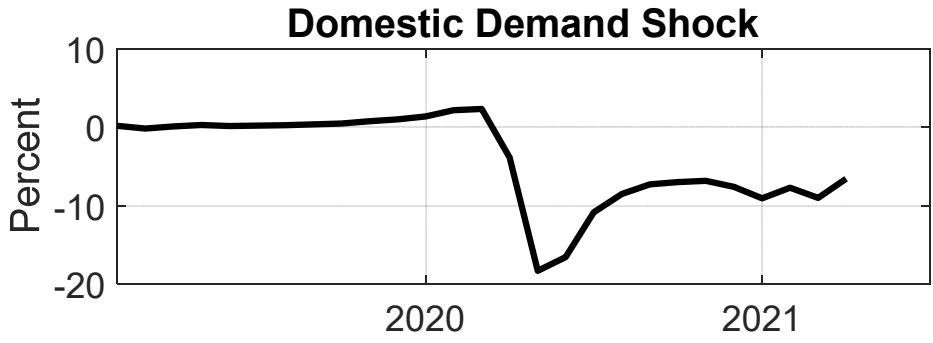

Foreign Demand Shock
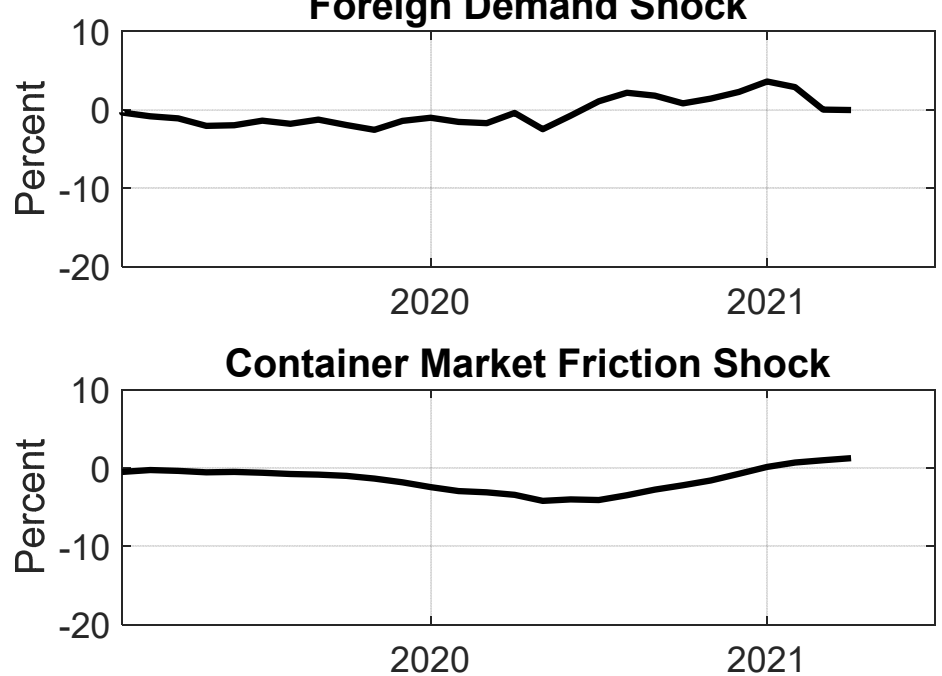

NOTES: Based on the cumulative effects of each shocks underlying the Bayes estimate of the impulse responses in Figure 5, while setting the other shock to zero. 
Figure 9: Historical Decomposition of Real Personal Consumption

2008.1-2010.6

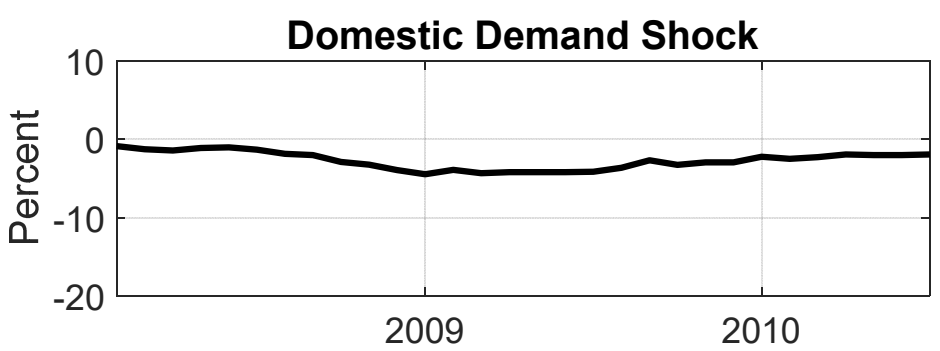

Foreign Demand Shock
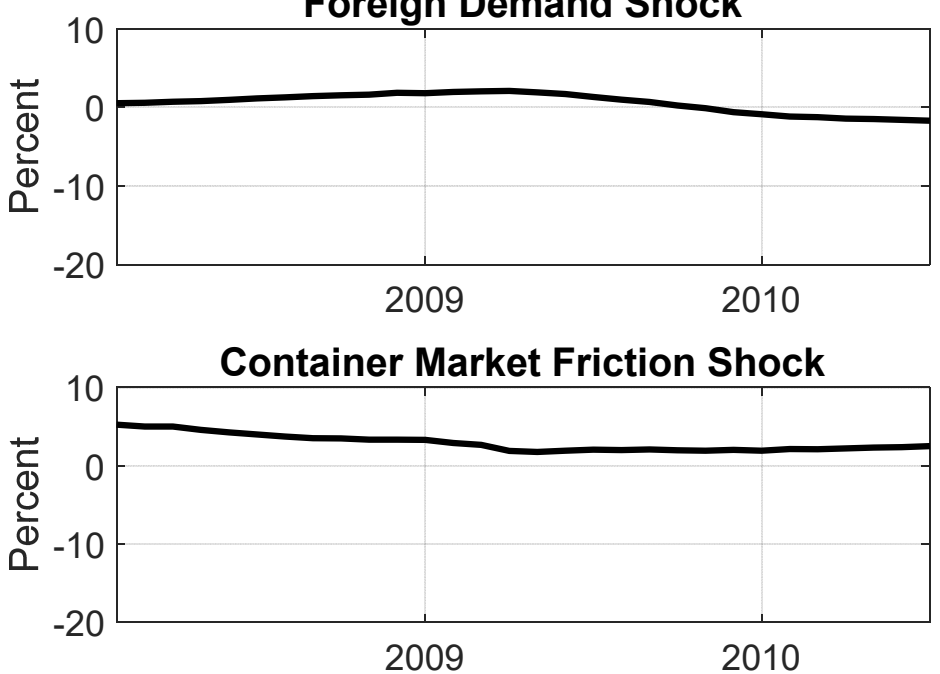

2019.1-2021.3

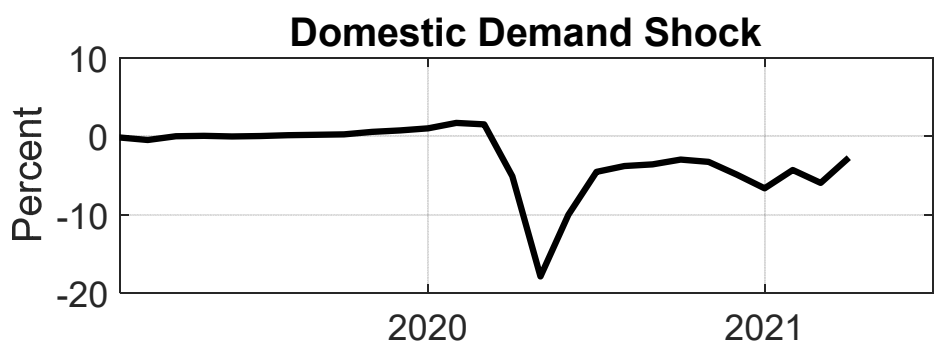

Foreign Demand Shock
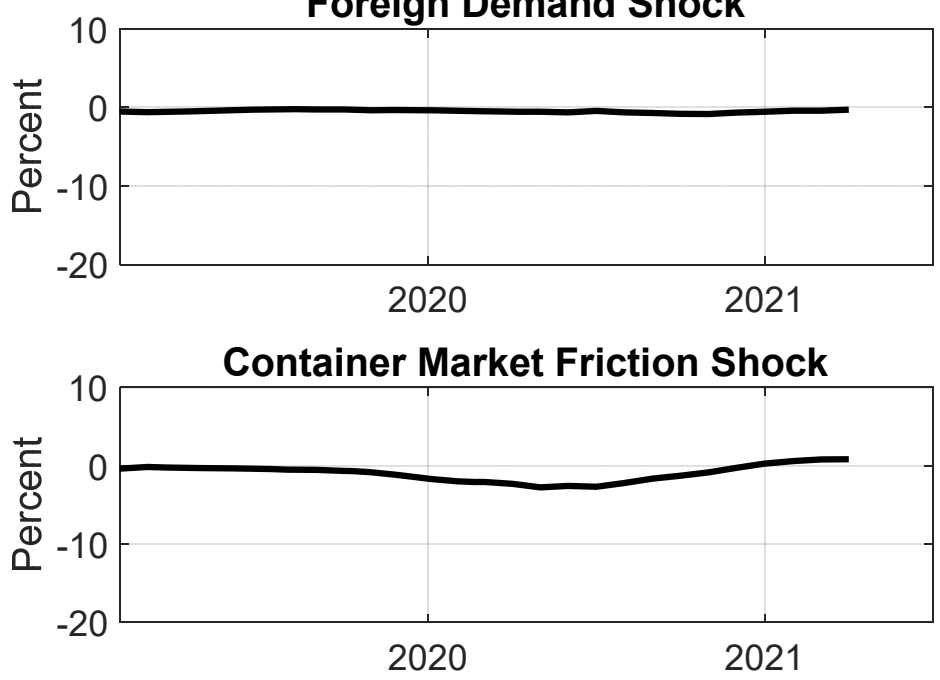

NOTES: Based on the cumulative effects of each shocks underlying the Bayes estimate of the impulse responses in Figure 5, while setting the other shock to zero. 
Figure 10: Historical decomposition of Real Personal Goods Consumption, 2019.1-2021.3
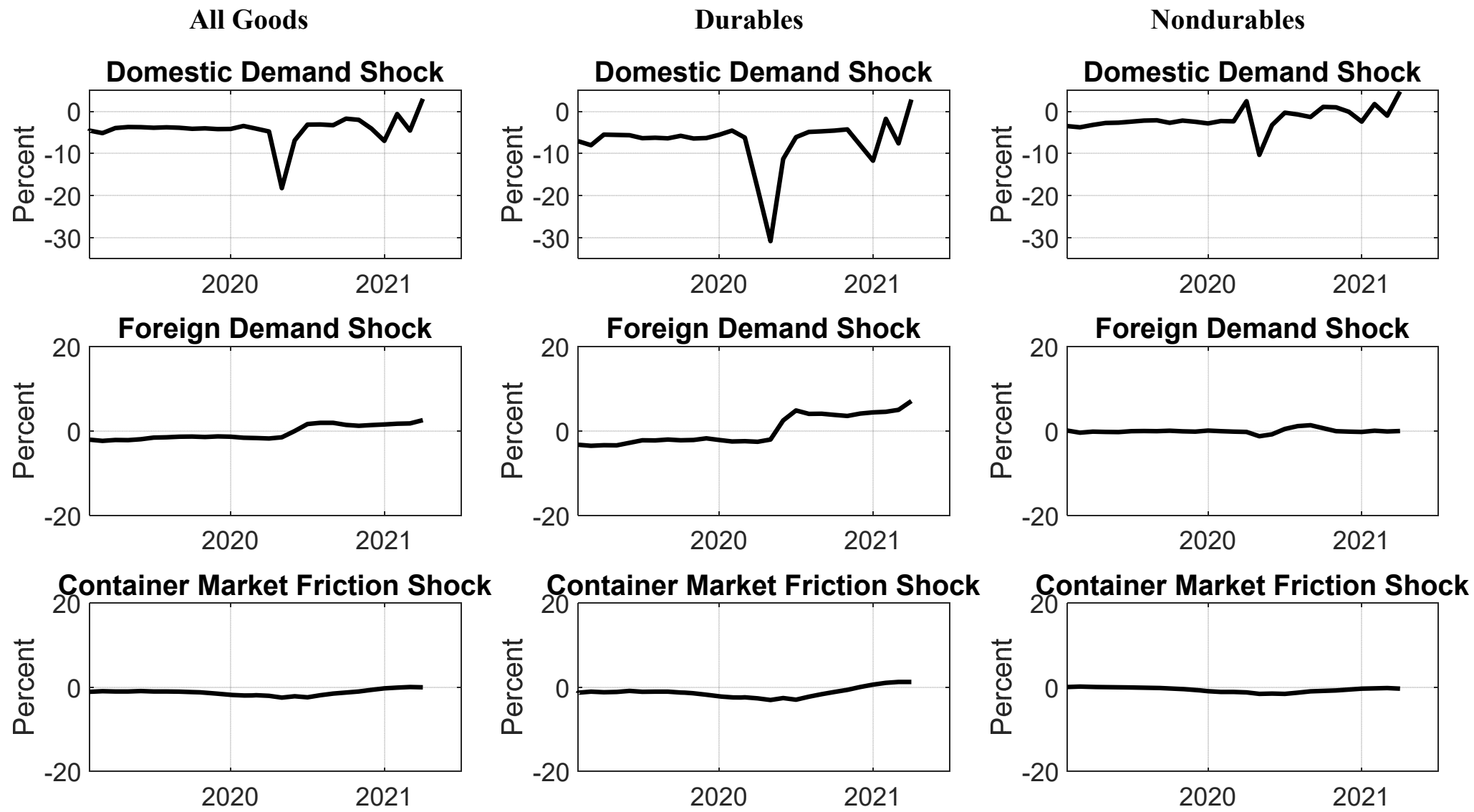

NOTES: Estimate from alternative VAR model with real personal consumption replaced by real personal goods consumption. 


\section{Appendix: The Prior Specification for the Structural VAR Model}

The $n$-dimensional reduced-form VAR model is estimated based on a diffuse uniformGaussian inverse Wishart prior, as in Karlsson (2013). The prior of the VAR slope parameter vector is $\beta \sim N\left(\beta_{0}, \Sigma \otimes \Omega_{0}\right)$, where the prior mean $\beta_{0}$ is set to zero and $\Omega_{0}$ is a diagonal

matrix with $j^{\text {th }}$ diagonal element $\left(\frac{1}{\sigma_{j}^{2}}\right)\left(\frac{0.2}{l^{2}}\right)^{2}, \sigma_{j}^{2}$ is approximated as the residual variance of an $\mathrm{AR}(1)$ regression for variable $j, l$ indicates the lag, and $\Sigma \sim \operatorname{IW}\left(S_{0}, \alpha_{0}\right)$ with

$$
S_{0}=\left(\alpha_{0}-n-1\right)\left(\begin{array}{cccc}
\sigma_{1}^{2} & 0 & 0 & 0 \\
0 & \sigma_{2}^{2} & 0 & 0 \\
0 & 0 & \ddots & 0 \\
0 & 0 & 0 & \sigma_{n}^{2}
\end{array}\right)
$$

and $\alpha_{0}=n+2$. 